\title{
Soviet Jews in World War II: Fighting, Witnessing, Remembering.
}

\author{
Ed. Harriet Murav and Gennady Estraikh. Borderlines: \\ Russian and East European Jewish Studies. Brighton: \\ Academic Studies Press, 2014. ISBN: 9781618113139. 268 p.
}

DOI: $10.31168 / 2658-3364.2020 .2 .24$

Катастрофа советского еврейства долгое время игнорировалась в СССР в пользу героического нарратива о Великой Отечественной войне, а в западном контексте стала частью общей трагедии еврейского Холокоста в Европе. Отличительные качества этих событий на территории бывшего СССР, как и отношение к ним выживших евреев, все еще требуют значительного внимания исследователей. Данная публикация является одним из первых серьезных шагов на пути к восполнению этого пробела. Одним из главных достижений данного сборника может быть отмечено сближение на общем фоне категорий «еврейское» - «советское» и Холокост - Великая Отечественная Война вне рамок частой для них противопоставленности. Редакторы и авторы сборника задают вопросы о том, как строилась и менялась идентичность советских евреев во время Второй Мировой Войны и Холокоста на территории Советского Союза, и показывают эти события глазами современников посредством уникального анализа множества мемуаров, дневников, корреспонденции, устной истории, поэзии, фотографии, кино и публицистики.

Книга поделена на две части - историческую и документально-интерпретативную. Первая часть объединена общей темой - советский еврей на войне. В первой главе Мордехай Альтшулер приводит ряд примеров того, как полностью ассимилированные советские военные возвращаются к своим этническим корням под влиянием травматических переживаний на фронте. Виды массовых казней и разграбленных синагог, а также внезапное ощущение растущего антисемитизма приводят людей, которые в остальном ничем не отличаются от других граждан СССР, к 
горькому осознанию собственной принадлежности к еврейскому народу. И тогда забытые еврейские «квадратные буквы», звуки идиша, или звезда Давида становятся проявлениями той скорби, к которой большинство в советском государстве равнодушно.

Во второй главе Джошуа Рубенстайн дает право голоса человеку, который во многом сформировал советский нарратив о войне и Холокосте Илье Эренбургу. Это приведенная с минимальными комментариями подборка знаковых статей Эренбурга в советской прессе, переведенных на множество языков и служивших для информирования о судьбе еврейских жертв и подвиге еврейских героев как в СССР, так и на западе.

Олег Будницкий поднимает в своей статье важнейшую тему «будней рядового Абрама», опираясь на богатый материал фронтовых дневников евреев. Читатель не только узнает о невыносимых условиях, с которыми столкнулся каждый солдат и офицер (вне зависимости от национальности) во время войны, но и получает картину ситуации с цензурой, пропагандой и антисемитизмом в Красной Армии.

Неожиданное сопоставление еврейского и казаческого образов выделяет статью Геннадия Эстрайха, которая, тем не менее, удивительно органично вписывается в сборник. Автор анализирует, как в советской литературе на идише и русском языках отразилось стремление еврейских писателей представить высшую степень героизации советского еврея, который в их интерпретации становится максимально маскулинизированным вплоть до приобретения черт казака. Это изображение отчасти призвано подчеркнуть фронтовой опыт сотен тысяч евреев в Красной Армии в том числе и в кавалерии, а отчасти демонстрирует, как образ казачества был популярен среди евреев в СССР в качестве образца брутальности и антипода традиционного представления о еврейской «феминности».

Продолжая тему евреев-героев, Аркадий Зельцер анализирует как менялась линия еврейского сопротивления в публикациях Эйникайт газеты на идише Еврейского Антифашистского Комитета. Он отмечает, что во время войны журналисты и писатели имели возможность подчеркивать отвагу и патриотизм евреев в армии и сопротивлении, поскольку это совпадало с интересом партийного руководства - вызвать поддержку на Западе. Однако, с ростом националистического шовинизма и поворотом пропаганды в сторону восхваления русского духа, образы еврейских героев, особенно связанных с легендарными примерами из еврейской истории, как, например, Бар Кохба, перестали казаться уместными в советском мейнстриме.

Вторая часть сборника представляет собой неоднородный набор источников и интерпретаций. Марат Гринберг и Хэрриет Мурав предлагают два очень разных метода интерпретации темы войны и Холокоста в поэзии советских евреев. Ольга Гершенсон обращается к первому в СССР 
фильму, изобразившему Холокост на экране - «Непокорённым» Марка Донского (1945). Фоторепортаж, как ключевой метод воспроизведения событий военных лет, представлен в подробном анализе Дэвида Шнира о роли и художественной особенности фотографий Евгения Халдея - автора самой известной фотографии водружения советского флага на Рейхстаге, а также свидетеля освобождения Будапештского гетто.

Сборник завершают отрывки из воспоминаний Бориса Слуцкого, Михаила Ромма и Анатолия Рыбакова. Эти материалы не так давно стали доступны и русскоязычному читателю, а на Западе публикуются впервые $^{1}$. К большому сожалению, места для такого рода свидетельств от первого лица в сборнике уделено немного. Также можно отметить, что практически отсутствуют (за исключением статьи Будницкого) упоминания роли еврейских женщин и их военных судеб. Данное упущение открывает интересную возможность для будущих исследователей. Из недостатков можно указать и на слабую связь послесловия профессора Цви Гительмана с содержанием сборника. Это послесловие скорее служит описанием основных исторических событий, роли СССР во Второй Мировой войне, Холокоста в Восточной Европе и места советских евреев в этой трагедии. Вероятно, такого рода историческая справка может быть полезна западному читателю, незнакомому с особенностями данного исторического периода.

Подводя итог, данная публикация, вне сомнения, открывает исключительно важную главу в исследовании советского еврейства. В соответствии с последними тенденциями в социальной истории Холокоста и Второй Мировой войны, упор в будущем, очевидно, должен быть сделан на изучение эго-документов, восстановление заглушенных в советскую эпоху голосов, которые помогут рассказать историю геройства и страдания. Из этого тома уже вырисовывается перспектива сложной идентичности советских евреев, которая сближает нарративы о Великой Отечественной Войне и Холокосте и воздает должное исторической несправедливости в игнорировании этими историями друг друга.

\section{Литература}

Слуцкий 2000 - Слуцкий Б.А. Записки о войне: Стихотворения и баллады. ЛОГОС, 2000. 348 с.

Ромм 2003 - Ромм М.И. Как в кино. Устные рассказы. Нижний Новгород: Деком, 2003. 256 с.

Рыбаков 1997 - Рыбаков А. Роман-воспоминание. М.: Вагриус, 1997. 378 с.

${ }^{1}$ См.: [Слуцкий 2000, Ромм 2003, Рыбаков 1997]. 
Olga Kartashova (New York, USA)

Scribal Department of Hebrew and Judaic Studies, New York University

Ph.D. student

E-mail:ok763@nyu.edu

ORCID: 0000-0001-6992-1586

\section{References}

Slutskii B.A., 2000, Zapiski o voine: Stikhotvoreniia i ballady. [Poems and ballads]. LOGOS, $348 \mathrm{~s}$.

Romm M.I., 2003, Kak v kino. Ustnye rasskazy. [As in a film. Oral stories.] Nizhnii Novgorod: Dekom, $256 \mathrm{~s}$.

Rybakov A., 1997, Roman-vospominanie. [Novel - memory] Moskva: Vagrius, $378 \mathrm{~s}$. 